UDC $821.124+82-143+811.1$

\title{
QUIS LEGET HAEC?
}

\section{Валерий Семенович Дуров}

Санкт-Петербургский Государственный Университет,

Российская Федерация, 199034, Санкт-Петербург, Университетская наб., 7-9; v.durov@spbu.ru

Автор статьи анализирует нестандартный случай использования инфинитива в роли объекта при безличном глаголе pudet в одной из элегий Тибулла (Tibull. 1, 73-74). На основании синтаксической функции инфинитива в данном употреблении автор предлагает рассматривать его морфологическую форму как аналогичную родительному падежу имени. Это наблюдение является частью небольшого филологического этюда в жанре memorabilia, посвященного выдающемуся филологуклассику А.К. Гаврилову. Воспоминания о чтении древних авторов под руководством Александра Константиновича, его пристальном внимании к каждому слову и подходе к комментированию античного текста послужили поводом для написания статьи.

Ключевые слова: латинский язык, Тибулл, синтаксические функции инфинитива, безличные глаголы.

«Кто это станет читать?» Такой вопрос задает сатирику Персию его воображаемый собеседник. Ответ незамедлителен: vel duo vel nemo (Pers. 1, 2-3) ${ }^{1}$.

Вот и я, пишущий эти строки, спрашиваю: кто их станет читать? Разве что двое. М. М. Позднев: он ответственный редактор выпуска, и А. К. Гаврилов: этот том посвящен его юбилею.

Отношение к комментариям у юбиляра особое. Вот одно из его суждений: «Примечания показались мне утопически подробными, какой-то коммунизм ученых мнений, где только поэзии нету места» ${ }^{2}$.

Можно ли сказать нечто новое, неизвестное прежде? Живший во II в. до н.э. Теренций, уравновешенный, здравомыслящий комедиограф, признает, что "nullum est iam dictum, quod non sit dictum prius" (Ter. Eun. 41), и потому открыто использует наследие греческих поэтов. У Иеронима, человека крайне эмоционального,

${ }^{1}$ Крылатой фразе Quis leget haec? предпослана цитата из Луцилия. О возможности соотнести haec с этой цитатой: Pozdnev, 2000, 387-391.

${ }^{2}$ Из письма А. К. Гаврилова М. Л. Гаспарову об одном ученом: Gasparov, 2000, 29.

(c) St. Petersburg State University, 2016 
страстного и неуступчивого, на этот случай ответ один: "pereant qui ante nos nostra dixerunt" (Hier. In Eccles. 1, 9 [Migne XXIII, 1071]) ${ }^{3}$.

Взыскательность Александра Константиновича к себе и своим научным исследованиям известна. «Традиционное филологическое мастерство, - пишет он, требует открытой внимательности к тексту, готовности мобилизовать с помощью собственной многообразнейшую чужую ученость по мере того, как будет нащупываться, что именно потребуется при решении той или иной проблемы» (Gavrilov, 2011, 329).

Помнится, в конце 1960-х Гаврилов, в то время аспирант, вел в студенческой группе, где учился и автор этих строк, занятия по латинскому языку. Читали Тибулла. Александр Константинович обстоятельно, ничего не пропуская, комментировал прочитанное. Прошло много лет, и уже со своими учениками читаю Тибулла я. Текст несложный, но есть над чем задуматься. Вот, к примеру, дистих, 1, 73-4:

nunc levis est tractanda Venus, dum frangere postes non pudet et rixas inseruisse iuvat.

В этой фразе две, казалось бы, однотипные конструкции с инфинитивами. Во второй rixas inseruisse iuvat инфинитив inseruisse - подлежащее, т.е. номинатив, в первой же frangere postes non pudet инфинитив frangere номинативом быть не может, так как безличный глагол pudet, подобно глаголам piget, poenitet, taedet, miseret, управляет винительным падежом субъекта, лица, испытывающего то или иное чувство, и родительным падежом объекта, причины чувства, например tui me miseret, mei piget - «тебя мне жалко, себя стыдно» ${ }^{4}$. Следовательно, инфинитив frangere надо понимать как родительный падеж действия, вызывающего чувство.

Что думали об этом латинские грамматики, не знаю. Но, если есть номинатив и аккузатив инфинитива, почему бы не быть и генитиву? Впрочем, утверждать это не берусь, памятуя об участи учителя латинского языка из «Современной идиллии» Салтыкова-Щедрина. Этот учитель, к своему несчастью, смешивал герундий с супином, за что по распоряжению начальства был привлечен к суду и вскоре умер. В решении суда было сказано: «Хотя учителя Кубарева за распространение в юношестве превратных понятий о супинах и герундиях, а равно и за потрясение основ латинской грамматики и следовало бы сослать на жительство в места не столь отдаленные, но так как он, состоя под судом, умре, то суждение о личности его прекратить, а сочиненную им латинскую грамматику сжечь в присутствии латинских учителей обеих столиц» 5 .

3 Эти слова - пояснение к Теренцию, раскрывающие подлинный пафос указанного места из пролога к «Евнуху». Приведя данную цитату, Иероним продолжает: "Unde praeceptor meus Donatus, cum istum versiculum exponeret", "Pereant, inquit, qui ante nos nostra dixerunt". В дошедших комментариях Доната к Теренцию цитируемой фразы не обнаруживается. Вероятно, Иероним слышал ее от своего учителя во время занятий.

${ }^{4}$ Из трагедии Энния «Александр» (Cic. Div. 1, 66). Этот пример приводит наш общий с А. К. Гавриловым учитель Я. М. Боровский: Borovskii, Boldyrev 1975, 144.

${ }^{5}$ Цит. по: Салтыков-Щедрин, 1988, 53. 


\section{Литература}

Pozdnev, M. Die Personenverteilung in Persius 1, 1-12. Hyperboreus 2000, 6, 387-399.

Боровский, Я. М., Болдырев, А.В. Учебник латинского языка для гуманитарных факультетов университетов. Изд. 4, доп. М., Высшая школа, 1975.

Гаврилов, А.К. О филологах и филологии: статьи и выступления разных лет. СПб., Изд-во СПбГУ, 2011.

Гаспаров М. Л. Записки и выписки. М., Новое литературное обозрение, 2000.

Салтыков-Щедрин М.Е. Собр. соч. В 10 т. Том 8. М., Правда, 1988.

Для цитирования: Дуров В. С. Quis leget haec? Philologia Classica 20166 11(1), 167-169.

DOI: $10.21638 / 11701 /$ spbu20.2016.115

\section{References}

Borovskii, Ya. M., Boldyrev, A.V. Uchebnik latinskogo yazyka dlia gumanitarnykh fakul'tetov universitetov. Izd. 4, dop. 1975 [Manual of the Lain Language for Humanitarian Faculties of the Universities. Ed. 4, ext.] Mocow, Vysshaia shkola,1975. (In Russian)

Gasparov, M.L. Zapiski i vypiski [Notes and Excerpts]. Moscow, Novoe literaturnoe obozrenie, 2000. (In Russian)

Gavrilov, A. K. O filologakh i filologii: Stat'i i vystupleniia raznykh let. [On Philologists and Philology: Articles and Speeches]. St. Petersburg University Pulishing House, 2011. (In Russian)

Pozdnev, M. Die Personenverteilung in Persius 1, 1-12. Hyperboreus 2000, 6, 387-399.

Saltykov-Shchedrin, M.E. Sobr. soch. V 10 t. Tom 8. [Collected Works. 10 vols. Vol. 8]. M., Pravda, 1988. (In Russian)

For citation: Durov V.S. Quis leget haec? Philologia Classica 2016, 11(1), 167-169.

DOI: $10.21638 / 11701 /$ spbu20.2016.115

\section{QUIS LEGET HAEC?}

Valery S. Durov

The author analyzes the unusual occurrence of the infinitive as an object of the impersonal verb pudet in Tibull. 1, 73-74. On the basis of the syntactic function of the infinitive, he suggests to consider its morphological form as analogous to the genitive case. This observation is a part of philological essay in the genre of memorabilia dedicated to the outstanding classical scholar Alexander K. Gavrilov. It is Gavrilov's attentive attitude to every word in the text and his approach to the commenting on ancient texts, that inspired the author to write this article.

Keywords: Latin, Tibullus, syntactic functions of Latin infinitives, impersonal verbs.

Received: 19.02.2016

Final version received: 26.04 .201 